\title{
AIST Superannuation Governance: Paper Examining International and Australian Governance Trends
}

\author{
Karen Volpato and Eva Scheerlinck \\ Australian Institute of Superannuation Trustees, Australia
}

\begin{abstract}
The Australian Government is seeking to introduce major changes to the governance of superannuation funds. Industry superannuation funds in Australia often have an executive board of directors in which the composition of the boards is based on equal representation of the number of directors elected by the Members and by the employer organisation. One of the major tenets of governance is the appointment of independent directors. The Government has issued a discussion paper in which it was suggested that this should be adopted by the superannuation funds. This paper argues on behalf of the Australian Institute of Superannuation Trustees (AIST) why this change is not necessary and how under the current model the funds are compliant with the governance standards of the Australian Prudential Regulation Authority (APRA) and the Australian Securities Exchange (ASX).
\end{abstract}

Key Words

Governance, Superannuation funds, Independent directors, Australian Institute of Superannuation

\section{Purpose of this Paper}

The Australian Institute of Superannuation Trustees (AIST) mission includes championing strong governance of the superannuation industry. AIST is committed to advancing the good governance practices and culture of not-for-profit superannuation funds. AIST believes that representative trustees offer the best governance model for Australian superannuation funds through their independence from profit-making financial institutions, their diversity and investor representation, and a unique culture of commitment and innovation. The governance model of not-for-profit funds is based on equal representation whereby an equal number of the fund's employer and employee-sponsored directors are nominated or elected to the fund's board with the overarching protection of a two-thirds majority vote on board decisions.

In November 2013, the Government issued its Better Regulation and Governance, Enhanced Transparency and Improved Competition in Superannuation Discussion Paper ("the Government's Discussion Paper"). The Government's

Copyright (C) 2015 Victoria University. This document has been published as part of the Journal of Law and Governance in both online and print formats. Educational and non-profit institutions are granted a non-exclusive licence to utilise this document in whole or in part for personal or classroom use without fee, provided that correct attribution and citation are made and this copyright statement is reproduced. Any other usage is prohibited without the express permission of the publisher.
Discussion Paper sought feedback on several issues, including the most appropriate definition and proportion of independent directors on superannuation boards. The Government's Discussion Paper includes an unproven underlying assumption that independent directors would improve current governance outcomes. The Financial System Inquiry

\footnotetext{
${ }^{1}$ Australian Government, (2013) Better Regulation and Governance, Enhanced Transparency and Improved Competition in Superannuation, Discussion. Australian Government. Available at: http://www.treasury.gov.au/ /media/Treasury/Consultations\%20and\%20Reviews/Consultations/2013/Better\%20regulation $\% 20$ and\%20governance/Key\%20Documents/PDF/Discussion_Paper.ashx
} 
Final Report ${ }^{2}$ has recommended the mandating of a majority of independent directors on the board of corporate trustees of public offer superannuation funds, including an independent chair; align the director penalty regime with managed investment schemes; and strengthen the conflict of interest requirements. In its submission in response to the Financial System Inquiry Final Report ${ }^{3}$, AIST has strongly contested the proposition that there are shortcomings that need attention, or that the Final Report recommendations will lead to better outcomes for members of not-for-profit funds. AIST believes that any such should not be taken lightly and should be considered in the context of international experience.

Following the Global Financial Crisis ("GFC"), a review of corporate governance practices was high on the agenda overseas. The microscope was placed on financial institutions (including pension funds) both in Europe and the USA.

This Paper was initially prepared for internal AIST use to inform its response to the Government's Discussion Paper, as this Paper examines post-GFC international reviews of corporate governance trends. This Paper now summarises:

- AIST's response to the Government's Discussion Paper - so far as governance matters are concerned. Our response to this as well as to the Financial Services Inquiry Final Report was informed by this Paper;

- International corporate governance trends, with particular focus on post-GFC reviews; and

- How not-for-profit superannuation funds meet ASX principles and banking and insurance company prudential standards.

Australia's superannuation funds are underpinned by and acting in the best interest of members' test, which is enshrined in legislation as well as trust law. Overseas commentators believe that 'best interest' tests should also be legislatively imposed on European banks - so that bank depositors' interests may be protected against banks only acting in the interests of shareholders. Australian not-for-profit superannuation funds exist only to benefit members.

Our research also found that overseas commentators such as the OECD strongly believed independence of thought and mind were more important than meeting a strict definition of being an 'independent director'. We also found that there is no evidence that 'independent directors' add value; and that members of superannuation funds should be suitably represented on superannuation fund boards (as already occurs through the equal representation model of Australia's not-for-profit superannuation funds).

\section{AIST's position on superannuation governance matters}

The superannuation industry is currently implementing a wide raft of changes, particularly in the area of fund governance. Following an extensive consultation period, with significant industry input, new Prudential Standards and guidance were introduced and a new suite of legal obligations in the Superannuation Industry (Supervision) Act 1993 ("SIS Act") has taken effect to strengthen superannuation fund governance and the duties and obligations of trustee directors. While the industry should always strive towards best possible governance practices, now is a time for consolidation to allow the heightened standards to impact governance practices in the industry.

AIST supports a light-touch regulatory approach where appropriate, while acknowledging the importance of the superannuation industry to Australia's economy, the retirement savings of working

\footnotetext{
${ }^{2}$ Financial System Inquiry Final Report, (2014). [online] Commonwealth of Australia. Available at: http://tinyurl.com/nx768z8 [Accessed 7 Apr. 2015].

${ }^{3}$ Australian Institute of Superannuation Trustees, (2014). Response to the Financial System Inquiry Final Report 31 March 2015. [online] Australian Institute of Superannuation Trustees. Available at: http://tinyurl.com/lj5gh2ul [Accessed 6 April. 2015].
} 
Australians and the compulsory nature of the system. However, any further reforms to the system should not only be considered in light of regulatory efficiency and cost, but also through a risk management lens. The ultimate benefit to members, in a system where that priority is paramount for trustees, should also be a key consideration for Government.

Notwithstanding these relatively recent developments, the Government is currently reviewing the board structures of super funds. The Government's Discussion Paper sought feedback on several key governance issues, including the most appropriate definition and proportion of independent directors on superannuation boards. The Financial System Inquiry Final Report has recently recommended the mandating of a majority of independent directors on the board of corporate trustees of public offer superannuation funds, including an independent chair; align the director penalty regime with managed investment schemes; and strengthen the conflict of interest requirements.

AIST believes the representative trustee system delivers superior results for members and does not support the mandating of independent directors -either as a majority or a 'one third' requirement. Rather, we support flexibility around the equal representation system with the SIS Act being amended to allow boards to appoint up to one third non-representative directors. AIST believes there is no evidence to suggest that mandating a majority of independent directors will benefit members of notfor-profit funds.

For equal representation boards the SIS Act limits the number of independent directors that such a board can appoint. AIST supports greater flexibility at law around this restriction and recommends that the legislation be amended to allow equal representation boards to appoint up to a third of their number from outside of the representative pool. AIST supports the equal representation model however, and believes that up to one-third independent directors preserves the nature of that system, while offering boards greater flexibility.

AIST points to the significant complexities that underlie an attempt to align the superannuation industry with other APRA-regulated industries and listed companies. Superannuation funds are set up as trusts, a structure that has significantly different foundations and obligations, and that is not easily merged with other operating structures. This trust structure has unique properties, which AIST believes are essential to the continued success of our system. It does however mean that alignment with other sectors may not be entirely possible in every respect. The governance models within the superannuation industry itself require different treatment for equal representation boards to those with a different structure. While we support the ASX Corporate Governance Principles and their definition of independence as it applies in the corporate arena, the straight adoption across into superannuation is unworkable due to the unique nature of the superannuation governance and operating models.

AIST believes that legal entities such as superannuation funds should not be subject to regulatory overlay when it to comes to choosing who governs and leads the business. The new Prudential Standards and the SIS Act very clearly articulate the roles and responsibilities of trustee entities and their boards and APRA's expectations as a regulator have also been clarified through the recent Stronger Super reforms. AIST submits that the regulator has sufficient powers to direct funds to make appropriate changes where it has concerns regarding governance or other risks, and that funds, operating within the law, should be able to choose directors and a Chair of the fund that is appropriate for the needs of the fund, and is ultimately in the best interests of members.

Australia's superannuation system has been independently reviewed, and was found in 2014, following the introduction of APRA's Prudential Standards, to be ranked amongst the world leaders (ranking of 3 out of 25 countries) on pension fund governance and integrity. ${ }^{4}$

\footnotetext{
${ }^{4}$ Australian Centre for Financial Studies and Mercer, (2014) Melbourne Mercer Global Pension Index, Melbourne Available at: http://tinyurl.com/omuvjxo
} 
If there is any change to the independent director requirements for superannuation funds, the definition of 'independent director' is crucial. It means different things in different contexts. The Financial Services Inquiry Final Report recommends that an arm's length definition should be adopted. Section 10(1) of the SIS Act adequately characterises non-representative directors for an equal representation board structure. The definition excludes employer sponsors and representatives of member and employer representative organisations. AIST in its submission noted that this exclusion is unnecessary as membership does not engender a material conflict that impacts on the director's ability to act with independence of mind and judgment.

AIST believes the current legal requirements set out in the SIS Act, APRA Prudential Standards and trust law, with regulatory oversight from APRA provide a sound framework for the management of conflicts of interest. SPS 521 and the new SIS Act amendments should be allowed time to impact fund governance arrangements.

\section{Research Section}

\section{Summary of Research Findings}

\section{Key findings}

- International commentators all note that good governance is important. Among other things, good governance is associated with good performance.

- Most countries favour a principlesbased - as opposed to a prescriptive approach to pension fund governance. In Australia, the ASX Corporate Governance Principles and the APRA Prudential Standards adopt a principles-based approach.

- Different models of pension fund governance are valuable. Of 22 OECD countries, the majority have equal representation boards [representatives of both members and employers], while another six have member representation.
- Prescribing independent directors is not the answer. Many international commentators, such as the OECD. strongly believe independence of thought and mind is more important than meeting a strict definition of being an 'independent director'. However, evidence regarding the value of that independent directors bring is not definitive, both here and overseas.

- Trust law underpins the strong governance of super funds and best protects beneficiary interests.

\section{Good governance is multi-dimensional}

The ongoing debate about superannuation/pension fund governance is complex and nuanced and all too often over-simplified by media commentators. The focus of government reviews tends to be centred around board composition, the prescription of independent directors and the legal foundation of super fund governance - trust law. Good governance, however, is achieved through the efficient interaction of many organisational features. Good governance should permeate the fund's entire operations and at all levels within the fund's management structure, such as clearly delineating the roles of the trustee board and management, accountability arrangements within administration and finance systems, and robust risk management systems. This includes the appropriate management of conflicts of interests. Any valid attempt to improve superannuation governance should therefore be multi-dimensional and informed by international pension fund governance best practice trends and guidelines. 


\section{Most countries favour a principles-based approach}

The OECD and European Commission ${ }^{5}$ (among others) found that a principles-based approach to governance rather than a prescriptive approach leads to greater transparency and accountability. Principles-based corporate governance codes in the UK and Europe use a 'comply or explain' model to strengthen accountability and transparency. Boards then actively engage with the principles to explain their reasoning to shareholders (in the case of companies) or beneficiaries for the decisions they make. In Australia, the ASX Corporate Governance Principles and the APRA Prudential Standards also adopt a principles- based approach.

\section{Skills plus independence of thought and judgment is critical}

The OECD and the EU have concluded that the objective for good governance should include having boards that:

- Are capable of objective and independent judgment; and

- Have the right mix of skills and experience.

\section{Prescribing independent directors on a board is not the answer}

The OECD has concluded that promoting competence on boards is more critical than a focus just on independence ${ }^{6}$. While the OECD states there is not an inherent conflict between independence and competence, it goes on to say that sometimes formal independence may be necessary while independence per se is never a sufficient condition for board membership. The OECD suggests that the question of independent directors may have been pushed too far in favour of negative lists (qualities a director should not have rather than what they should) and this may have led to qualifications (as an example of positive board attributes) or suitability being of secondary importance.

In the United States, the stock exchange rules for listed companies are prescriptive - and independent directors are mandatory. Many believe US independent director requirements are easily avoided by selecting directors who are 'legally' but not actually independent. ${ }^{7}$

\section{Different models of corporate governance are valuable}

As noted by the OECD, a principles-based corporate governance model enables different governance structures to be implemented - and caters even for governance models that don't yet exist. A 2008 OECD Working Paper on Pension Fund Governance ${ }^{8}$ concluded that employee or member representation could ensure a better alignment of the interests of the board with the fund beneficiaries. The OECD Paper notes this needs to be balanced against the need for experience and knowledge. AIST notes that APRA's fit and proper standards deal with these requirements. Of the 22 countries reviewed

\footnotetext{
${ }^{5}$ Organisation for Economic Co-operation and Development, (2010). Guidelines for Pension Fund Governance. Organisation for Economic Co-operation and Development; Organisation for Economic Co-operation and Development, (2010), Corporate Governance and the Financial Crisis: Conclusions and Emerging Good Practices to Enhance Implementation of the Principles Organisation for Economic Co-operation and Development; European Commission, (2010). Green Paper 2010 Calling for ways to improve corporate governance in financial institutions, Brussels. European Commission.

${ }^{6}$ Organisation for Economic Co-operation and Development, (2010), Corporate Governance and the Financial Crisis: Conclusions and Emerging Good Practices to Enhance Implementation of the Principles Organisation for Economic Cooperation and Development. Available at: http://tinyurl.com/lsg8qet

${ }^{7}$ Scott, H. and Dallas, G. (2006). Mandating Corporate Behaviour: Can One Set of Rules Fit All? Available at: http://www.law.harvard.edu/programs/about/pifs/research/publications/s\&p6.05monograph.pdf

${ }^{8}$,Stewart, F. and Yermo, Y. (2008). Working Paper on Pension Fund Governance, Challenges and Potential Solutions, Organisation for Economic Co-operation and Development. Available at: http://www.oecd.org/finance/privatepensions/41013956.pdf
} 
by the OECD, 13 have equal representation and a further six require some form of member representation on the board.

Regarding 'best interests tests', the $\mathrm{EU}^{9}$ has called for legislation governing listed companies to have a legal 'duty of care to non-shareholders such as bank depositors' imposed on board directors. Australian superannuation boards are already required to act in the best interests of beneficiaries.

International commentators all note that good governance is important. Among other things, good governance is associated with good performance. ${ }^{10}$

Whether independent directors add value to performance is unclear. The jury is out on this issue both here and overseas. But there is widespread consensus that skills, experience, and independence of thought and judgment are critical. These key factors should be the focus of any moves to improve the governance of superannuation (indeed, they are a key focus of APRA's new standards on superannuation governance), rather than requiring certain 'types' of directors, such as independent directors.

\section{Part One - Corporate governance and why it matters}

\subsection{Why good governance matters}

Good governance of an organisation is associated with good performance ${ }^{11}$. The governance of the Australian superannuation system is strong. Australia's superannuation system has been independently reviewed, and was found in 2014, following the introduction of APRA's Prudential Standards, to be ranked amongst the world leaders (ranking of 3 out of 25 countries) on pension fund governance and integrity. ${ }^{12}$ APRA statistics show not-for-profit funds using the equal representation model have outperformed for profit funds. ${ }^{13}$ Not-for-profit superannuation funds have a very clear focus - they exist only to benefit members. Their focus is not swayed by shareholders or other parts of large financial conglomerates. Strong trustee governance practices reduce the potential risks faced by a superannuation fund with flow-on effects for the fund's enduring stability and sustainability. Good performance and the enduring stability and sustainability of a fund are fundamental to a member's retirement benefit.

\subsection{What is corporate governance?}

The UK Cadbury Committee on the Financial Aspects of Corporate Governance 1992 produced a muchquoted definition of corporate governance.

'Corporate governance is the system by which companies are directed and controlled. Boards of directors are responsible for the governance of their companies. The shareholders' role in governance is to appoint the directors and the auditors and to satisfy themselves that an appropriate governance structure is in place. The responsibilities of the board include setting the company's strategic aims, providing the leadership to put them into effect, supervising the management of the business and

\footnotetext{
9 European Commission, (2010). Green Paper 2010 Calling for ways to improve corporate governance in financial institutions, Brussels. European Commission.

Available at: http://ec.europa.eu/internal_market/company/modern/corporate_governance_in_financial_institutions_en.htm

${ }^{10}$ Johnson, K. and de Graaf, F. (2009). Modernising Pension Fund Legal Standards for the $2 \overline{1}^{\text {st }}$ Century, Organisation for

Economic Co-operation and Development. Available at:

http://www.oecd.org/corporate/ca/corporategovernanceprinciples/42670725.pdf Feb 2009

${ }^{11}$ Johnson, K. and de Graaf, F. (2009). Modernising Pension Fund Legal Standards for the $21^{\text {st }}$ Century, Organisation for

Economic Co-operation and Development. Available at:

http://www.oecd.org/corporate/ca/corporategovernanceprinciples/42670725.pdf Feb 2009

12 Australian Centre for Financial Studies and Mercer, (2014) Melbourne Mercer Global Pension Index, Melbourne

Available at: http://tinyurl.com/omuvjxo

${ }^{13}$ Medianet, (2014). , APRA Statistics show not-for-profit funds outperform. (online) Available at:

http://medianet.com.au/releases/release-details?id=792894
} 
reporting to shareholders on their stewardship. The board's actions are subject to laws, regulations and the shareholders in general meeting.'

While the above definition is clearly appropriate in a corporate setting where shareholders are key stakeholders, it does not however deal with the unique nature of organisations that exist in a trust structure without shareholders. As AIST and IFF's A Fund Governance Framework for Not-for-Profit Superannuation Funds ${ }^{14}$ notes, "high standards of trustee governance amount to more than mere compliance with legislative and regulatory requirements and prudent fiscal management. An effective governance framework begins with clearly defined powers and roles of trustees, chief executive officers and superannuation fund management. It includes articulated systems and relationships that underpin supervision, responsibility and accountability arrangements within the fund's administration and operation. It also incorporates robust risk management systems that identify, monitor and mitigate potential risks. Good governance policies and practices should permeate the fund's entire operations and all levels within the fund's management structure, forming an essential part of the fund's culture. It should also be specific to the fund, taking into account size, scale, membership, and unique qualities of the fund as set out in their trust deed and governing documents."

\section{Part Two - Overview of Corporate Governance Trends}

\subsection{Introduction}

This section examines corporate governance trends both overseas and within Australia. A spotlight was focussed on European and US corporate governance practices within financial institutions following the GFC. In summary:

- A principles-based - rather than using prescriptive definitions - is the preferred approach.

- Promoting competence on boards is more important than a focus on 'independent directors'.

- It is highly contentious whether 'independent directors' add value given corporate governance is multi-dimensional.

- Member representation on boards can ensure a better alignment of the board with superannuation fund members.

\subsection{OECD, EU and Australia}

\subsubsection{A principles based approach is adopted}

The OECD, EU Commission and Australia use a principles-based approach to corporate governance. Any model (now or future) could be tested against the principles. Such principles-based corporate governance codes in UK and Europe use a 'comply or explain' model. This model heightens the levels of accountability and transparency, more so than a prescriptive approach, as boards have to actively engage with the principles to explain their reasoning to shareholders or beneficiaries. Even post the GFC, international commentators believe that a principles-based governance approach to financial institution corporate governance is preferable to a prescriptive approach:

- OECD Guidelines for Pension Fund Governance June $2009^{15}$ notes that the governing body should be accountable and have final responsibility, and recognises that different models may be used to achieve this.

- OECD Corporate Governance and the Financial Crisis: Conclusions and Emerging Good Practices to Enhance Implementation of the Principles ${ }^{16}$ reinforces the OECD principles.

\footnotetext{
${ }^{14}$ Australian Institute of Superannuation Trustees and Industry Funds Forum, (2014). A Fund Governance Framework for Not-for-Profit Superannuation Funds, Third edition. Available at:

http://www.aist.asn.au/media/12822/2014 FundGov Framework V3.pdf

${ }^{15}$ Organisation for Economic Co-operation and Development, (2009). OECD Guidelines for Pension Fund Governance, Organisation for Economic Development and Co-operation. Available at: http://tinyurl.com/odoyat9

${ }^{16}$ Organisation for Economic Co-operation and Development, (2010). Corporate Governance and the Financial Crisis:

Conclusions and emerging good practices to enhance implementation of the Principles, Organisation for Economic
} 
- European Commission Green Paper 2010 Calling for ways to improve corporate governance in financial institutions ${ }^{17}$ (which includes banks, insurance companies and pension funds) supports the OECD principles-based approach.

- European Banking Federation's response ${ }^{18}$ to the European Commission Green Paper 2010 says that corporate governance should be principles-based, balanced and adequately flexible to reflect different national structures and business models

(ie. recognising different EU models).

In Australia, the ASX Corporate Governance Principles and APRA's prudential supervisory model have similarly adopted a principles-based approach.

\subsubsection{OECD and EU on 'independents'}

- OECD Guidelines for Pension Fund Governance June $2009^{19}$ state that the governing body should be suitable through having a mix of skills, including fit and proper criteria.

- OECD Corporate Governance and the Financial Crisis: Conclusions and Emerging Good Practices to Enhance Implementation of the Principles ${ }^{20}$ reinforces OECD principles and identifies weaknesses in board practices. They state the objective should be to create boards capable of objective and independent judgment. They further noted that while there is not an inherent conflict between independence and competence, sometimes formal independence may be necessary but never a sufficient condition for board membership. When using a principlesbased approach, the OECD argues that the principle should be that the board is capable of exercising independent and objective judgment, alongside skills, fitness and propriety. The OECD goes on to state that:

- Promoting competence on boards is more critical than a focus merely on independence;

- The question of independent directors may have been pushed too far in favour of negative lists and this may have led to qualifications (eg. positive list of board attributes) or suitability being of secondary importance in considering new board recruits; and

- Independence of thought and judgment is important.

- European Commission Green Paper 2010 calling for ways to improve corporate governance in financial institutions ${ }^{21}$ recommends widening of the fit and proper test to include the evaluation of expertise and individual qualities of candidates - and balance between independence and skills. Interestingly, the EU notes that for the for-profits (eg. banks) there should be a strengthening of legal liability for directors through a 'duty of care' to take into account interests of (bank) depositors. In superannuation in Australia this requirement is already in place in the Superannuation Industry (Supervision) Act 1993.

\footnotetext{
Development and Co-operation. Available at: http://www.oecd.org/corporate/ca/corporategovernanceprinciples/44679170.pdf

${ }^{17}$ European Commission. (2010). Green Paper: Corporate governance in financial institutions and remuneration policies, Brussels, European Commission. Available at: http://ec.europa.eu/internal_market/company/docs/modern/com2010_284_en.pdf

18 European Banking Federation (2010). EBF Response to the European Commission's Green Paper on Corporate Governance in financial institutions, Brussels, European Banking Federation. Available at: http://www.ebffbe.eu/uploads/documents/positions/CorpGov/6-\%20September\%202010-D1313D-2010EBF\%20response\%20Corporate\%20Governance\%20GP\%20-\%20final\%20version\%20-\%20clean.pdf

${ }^{19}$ Organisation for Economic Co-operation and Development, (2009). OECD Guidelines for Pension Fund Governance, Organisation for Economic Development and Co-operation. Available at: http://tinyurl.com/odoyat9

${ }^{20}$ Organisation for Economic Co-operation and Development, (2010). Corporate Governance and the Financial Crisis: Conclusions and emerging good practices to enhance implementation of the Principles, Organisation for Economic Development and Co-operation. Available at:

http://www.oecd.org/corporate/ca/corporategovernanceprinciples/44679170.pdf

${ }^{21}$ European Commission, (2010). Green Paper 2010 Calling for ways to improve corporate governance in financial institutions, Brussels. European Commission.

Available at: http://ec.europa.eu/internal_market/company/modern/corporate_governance_in_financial_institutions_en htm
} 
- European Banking Federation's response to the European Commission Green Paper 2010 supports diversity of board member profiles with a focus on professional skills, with the furthering of a board's overall efficiency being a primary focus when considering the composition of the board.

\subsubsection{Composition of superannuation boards - OECD countries}

A 2008 OECD Working Paper on Pension Fund Governance ${ }^{22}$ suggests that employee or member representation can ensure a better alignment of the interests of the board with the fund beneficiaries. The Paper goes on to comment that this needs to be balanced against the need for experience and knowledge. In Australia, the fit and proper requirements deal with this matter. The OECD Paper provides the following summary of representation on superannuation boards across various countries:

\begin{tabular}{|c|c|}
\hline Australia & $\begin{array}{l}\text { Non-public offer funds (company and industry-wide funds) must have an equal number of } \\
\text { employer representatives and member representatives on the board of directors of the } \\
\text { corporate trustee or in the board of trustees. }\end{array}$ \\
\hline Austria & $\begin{array}{l}\text { The board of supervisors of the pension fund may have two seats fewer for employee } \\
\text { representatives than for the sponsoring employer or other shareholders of the pension fund. }\end{array}$ \\
\hline Belgium & $\begin{array}{l}\text { The board of directors of a pension fund must have equal representation of employers and } \\
\text { employees. }\end{array}$ \\
\hline Brazil & $\begin{array}{l}\text { At least one third of the supervisory board and the audit committee must be composed of worker } \\
\text { representatives. }\end{array}$ \\
\hline Canada & $\begin{array}{l}\text { There are no requirements for single employer plans. Multi-employer plans established pursuant } \\
\text { to a collective agreement are governed by a board of trustees composed in accordance with the } \\
\text { plan or collective agreement (typically equal representation). }\end{array}$ \\
\hline Germany & $\begin{array}{l}\text { Supervisory Board: employee representation depends on the number of employees in the } \\
\text { pension fund, with a maximum of equal representation. }\end{array}$ \\
\hline Hungary & Mandatory pension funds must have member representatives in their board of directors. \\
\hline Iceland & The board of the pension fund must have equal representation of employers and employees \\
\hline Ireland & No requirement for employee representation. \\
\hline Israel & No requirement for employee representation. \\
\hline Italy & $\begin{array}{l}\text { The general assembly and the board of directors must each have equal representation of } \\
\text { employers and employees. }\end{array}$ \\
\hline Japan & $\begin{array}{l}\text { The Board of Representatives of Employee Pension Funds must have equal representation of } \\
\text { employers and employees. }\end{array}$ \\
\hline Mexico & No requirement. \\
\hline Netherlands & The board of the pension fund must have equal representation of employers and employees. \\
\hline Norway & $\begin{array}{l}\text { The board of the pension fund must have at least as many employee as employer } \\
\text { representatives. }\end{array}$ \\
\hline Poland & $\begin{array}{l}\text { Not less than half of the members of the supervisory board of the occupational pension society } \\
\text { should be nominated by the members of the fund. }\end{array}$ \\
\hline Spain & $\begin{array}{l}\text { The majority of the control commission must be selected by plan members and beneficiaries. } \\
\text { No requirement for member representation in the board of pension fund management } \\
\text { companies. }\end{array}$ \\
\hline South Africa & At least half of trustees must be elected by plan members. \\
\hline Sweden & The board of the foundation must have equal representation of employers and employees. \\
\hline Switzerland & $\begin{array}{l}\text { The supreme council of a pension fund must have equal representation of employers and } \\
\text { employees. }\end{array}$ \\
\hline $\begin{array}{l}\text { United } \\
\text { Kingdom }\end{array}$ & At least one third of trustees must be member-nominated. \\
\hline $\begin{array}{l}\text { United } \\
\text { States }\end{array}$ & $\begin{array}{l}\text { No requirements for single-employer funds. Multi-employer (Taft-Hartley) funds must have } \\
\text { equal representation of employers and employees. }\end{array}$ \\
\hline
\end{tabular}

\footnotetext{
${ }^{22}$ Stewart, F. and Yermo, Y. (2008). Working Paper on Pension Fund Governance, Challenges and Potential Solutions, Organisation for Economic Co-operation and Development. Available at: http://www.oecd.org/finance/privatepensions/41013956.pdf
} 


\subsection{USA}

\subsubsection{Companies - prescriptive approach applied}

The experience in the US is different to that of the UK, OECD and European Commission, with various stock exchanges (eg. NYSE) having a prescriptive based approach. However, US commentators have mentioned that US rules will need to become more flexible. A good summary can be found in a 2013 Harvard Law School paper ${ }^{23}$ where the highly prescriptive nature of US corporate regulation is reviewed. This review states that the US appears to believe that its predominance as an international capital market permitted it to impose its own regulatory rules without fear of losing market share. This situation has changed due to the ability to mobilise large amounts of capital and increased trading on foreign markets. If this is true, then US rules will have to become more flexible and we may see a move from the present model to one of comply or explain.

\subsubsection{USA companies and 'independents'}

The US models of corporate governance require independent directors. As noted earlier in this Paper, many believe US independent director requirements are easily avoided by selecting directors who are 'legally' but not actually independent.

The New York Stock Exchange defines independent as "no director qualifies as independent unless the board of directors affirmatively determines that the director has no material relationship with the listed company, either directly or as a partner, shareholder or officer of an organisation that has a relationship with the company." ${ }^{24}$

In the US, criticism of the need to appoint independents questions whether the directors are independent of judgment. This is because the majority shareholders accept the nomination of the board. So, in the end, the so-called 'independent' knows who appointed them, and this may give rise to a potential conflict. An interesting article from the Kellogg School of Management analyses whether having independent directors adds to performance. ${ }^{25}$ In summary, the report finds that there is a relatively small difference in returns earned by executives and independent directors but that they do earn higher returns than the market this has not however been the case in Australian superannuation sector - see for example research undertaken by the University of Melbourne. ${ }^{26}$

In the US, the main areas of debate around 'independents' centres around who appointed them (are they beholden to the board and majority shareholders?), whether independents are as good as company executives who are also directors, and how remuneration practices might sway decisions.

\subsubsection{USA pension schemes - a non-prescriptive approach}

Most US employee benefit plans (including pension plans) are governed by the Employee Retirement Income Security Act 1974 ('ERISA'). The main features of ERISA so far as corporate governance is concerned are:

- Those exercising control have fiduciary responsibilities.

- There is to be at least one named fiduciary with the authority to control and manage the plan.

\footnotetext{
${ }^{23}$ Scott, H. (2005). A Global Perspective on Corporate Governance, Credit Week. Available at: http://www.law.harvard.edu/programs/about/pifs/research/publications/5scott.pdf

${ }^{24}$ New York Stock Exchange, (2014). New York Stock Exchange Listed Company Manual. Section 303A.02. Available at: http://nysemanual nyse.com/LCMTools/PlatformViewer.asp?selectednode=chp_1_4_3\&manual=02Flcm $\% 2 \mathrm{Fsections} \% 2 \mathrm{Fl}$ $\mathrm{cm}$-sections $\% 2 \mathrm{~F}$

${ }_{25}$ Ravina, E. and Sapienza, P. (2009). What do Independent Directors Know? Evidence from their trading, Kellogg School of Management. Available at: http://www kellogg.northwestern.edu/faculty/sapienza/htm/ravina_sapienza.pdf

${ }^{26}$ Lawrence, J. and Stapledon,G. (1999). Do Independent Directors Add Value? The University of Melbourne. Available at: http://www.law.unimelb.edu.au/files/dmfile/IndependentDirectorsReport2.pdf
} 
- There are no member representation requirements for single employer funds, but there must be member representation on multi-employer funds.

- Fiduciaries are to run the plan solely for the interests of the participants and beneficiaries.

- Plans are to be run with well-documented decision-making processes, comply with laws and disclosure requirements, monitor vendor fees for reasonableness and service quality, and regularly assess plan performance.

While US listed companies have prescriptive listing requirements, most US employee pension plans are provided with "significant latitude in how plan sponsors design and conduct plan governance, eg. the creation and composition of specific benefit plan committees, their responsibilities, and the types of governance related documents they use. However, this does not imply that governance can be ad hoc or unplanned. Rather, the complexities of ERISA's many requirements, and the potential liability to fiduciaries if they breach their duties and to employers for compliance failure, create a pressing need for a thoughtfully constructed plan governance system." 27

In December 2011, Towers Watson published The New Governance Landscape, Implications from the 2011 Towers Watson US Retirement Plan Governance Survey. Key findings include:

- Processes of decision making vary widely.

- Respondents saw top governance challenges as retirement benefit costs and regulatory complexity.

- Less than half regularly assess the plan decisions against specific metrics.

\subsubsection{USA pension schemes - no requirement to have 'independents'}

In the case of public pension plans, representatives of the sponsoring organisation, current employees, beneficiaries and independents of US public pension plans comprise the boards. ${ }^{28}$ While there is no single code of governance practice in the US, individual funds such as CalPERs have developed their own codes of practice, which mention the topic of independence. CalPERS sees independence as the cornerstone and that boards should be comprised of at least a majority of 'independent directors'. CalPERS notes that the definition approach alone may be insufficient and boards must embrace independence. CalPERS has a prescriptive definition of independence. ${ }^{29}$ It includes that an independent is not affiliated with a not-for-profit entity that receives contributions from the company that exceed the greater of $\$ 200,000$ or $2 \%$ of consolidated gross revenue. CalPERS adopts the International Corporate Governance Network (ICGN) Principles.

\subsection{Have 'independents' added value?}

\subsubsection{Good governance delivers results - Australia's not for profit superannuation funds outperform}

Good governance of an organisation is associated with good performance. In the case of the Australian superannuation system:

\footnotetext{
${ }^{27}$ Towers Watson U.S. Retirement Plan Governance Survey, (2011). The New Governance Landscape, Implications from the 2011.

Towers Watson USA. Available at: file://Users/Karen/Downloads/Towers-Watson-US-Pension-Governance-Survey-2011Implications\%20(1).pdf

${ }^{28}$ Harper, J.T. (2008). Board of Trustee Composition and Investment Performance of US Public Pension Plans. Oklahoma State University, Available at:

http://www rijpm.com/admin/article_files/Joel_Harper_Board_of_Trustee_Composition_and_Investment_Performance_of_ US Public Pension Plans February 2008.pdf

${ }^{29} \bar{C}$ CalPERS $\bar{S}$ definition of 'independent' is included at page 54 of http://www.calpers-governance.org/docs-

sof/principles/2011-11-14-global-principles-of-accountable-corp-gov.pdf
} 
- Australia ranks second out of 25 countries $^{30}$.

- Not-for-profit superannuation funds have outperformed for profit funds ${ }^{31}$.

\subsubsection{Jury is out on whether 'independent' directors add value}

\section{Corporate governance is multi-dimensional}

In its 2008 report Governance and Performance in Corporate Britain, ${ }^{32}$ the Association of British Insurers (ABI) examined whether good governance delivers performance. The ABI operates the Institutional Voting Information Service which analyses UK listed companies in relation to levels of compliance with corporate governance best practice. The Report covers the boom period before the GFC, yet still finds (as did the Harvard study) that investors in listed companies put a premium on good governance. The Report notes the following:

- Corporate governance involves the interaction of many organisational features in complex ways. Assessment of corporate governance should therefore be equally multi-dimensional.

- One size of governance does not fit all.

- 'Independent directors' is raised in the context of whether there are sufficient non-executive directors to balance the number of executives on the board.

- Other factors include the appropriateness of performance targets, remuneration practices, composition of audit committees, and shareholding packages in excess of $40 \%$.

As a comment, the ABI Report highlights the principle that the appointment of independent directors as a single factor does not equate to good corporate governance.

\section{Contentious issue as to whether independent directors add value}

\section{Australia}

There are many studies on this topic - most concluding that there is no empirical evidence either way. Here is a summary of one Australian study.

A 2013 research study conducted by the Australian School of Business - Shareholders suffer from independent directors $\mathrm{s}^{33}$ - suggests that independent directors increased the pay of CEOs (not taking into account how well they performed) - and this has diminished shareholders' wealth. Professor Swan believes that this is because independent directors do not have knowledge of the industry or the company. It should be noted that Professor Swan is comparing results with pre-2003, when listed companies were not required under ASX listing rules to have a majority of 'independent' directors.

\section{Commentators divided even in USA, where Stock Exchanges have prescribed independents}

Professor Donald C Clarke in his article, Three Concepts of Independent Director, ${ }^{34}$ notes that "despite the surprisingly shaky support in empirical research for the value of independent directors, their desirability seems to be taken for granted in policy-making circles. ... Independent directors have long been viewed as a solution to many corporate governance problems. Well before the Enron and WorldCom scandals, the New York Stock Exchange already required the presence of independent directors on audit committees, and in the

\footnotetext{
${ }^{30}$ Australian Centre for Financial Studies and Mercer, (2014) Melbourne Mercer Global Pension Index, Melbourne Available at: http://tinyurl.com/omuvjxo

${ }^{31}$ Industry Super Australia, (2015). Industry super fund outperformance reinforces undivided loyalty model | Industry Super Australia. [online] Available at http://tinyurl.com/jwcc3qe [Accessed 13 March 2015].

${ }^{32}$ Selvaggi, M. and Upton, J. (2008). Governance and Performance in Corporate Britain, Association of British Insurers. Available at: http://www.gmiratings.com/noteworthy/ABI_Feb_2008.pdf

${ }^{33}$ Professor Swan, P. (2013). Shareholders suffer from independent directors. University of New South Wales, Australian School of Business. Available at:

http://www.asb.unsw.edu.au/newsevents/mediaroom/media/2013/august/Pages/shareholders-suffer-from-independentdirectors.aspx

${ }^{34}$ Clarke, D. (2007). Three Concepts of the Independent Director. George Washington University Law School. Available at: http://scholarship.law.gwu.edu/cgi/viewcontent.cgi?article=1045\&context=faculty_publications
} 
United States, insider-dominated boards have been rare for years. ... Some studies have even found a negative correlation between board independence and corporate performance."

The article goes on to comment that there is significant disagreement as to how 'independence' is defined. For example, those who see the independent director primarily as a defender of shareholder interests against management will naturally see more shares being held as beneficial. Those who see the independent director as someone untainted by any financial interest in the company are suspicious of share ownership. Professor Clarke concludes by saying that we do not even know what we mean when we talk about the independent director and that therefore, any jurisdiction planning to include independents should think carefully about the purposes and objectives for including independents.

\subsubsection{Independents and the need for diversity and specific sector training}

As noted by the $\mathrm{EU}^{35}$, diversity on boards (especially of non-executive board members) is one of the key issues of corporate governance: 'Empirical evidence highlights the benefits of diversity for corporate governance both in terms of efficiency and better monitoring. Diversity, not just of gender but also of race and social background, and the presence of employee representatives, broadens the debate within boards and helps, as some say to avoid the danger of narrow group think.'

In examining the causes of the GFC, the EU goes on to say that one of the interviews in their case studies said that it is 'difficult for supervisory board members without a background in banking to understand the range of different complex products; and further that Lord Myners in a review of the banking sector by the House of Commons Treasury Committee 2009 said that banks were not focussing on the need to recruit non-executives with specific technical expertise and experience in the banking sector.

This perhaps points to the need for directors to have specific training and expertise in the superannuation sector, as well as meeting the fit and proper requirements. Recently, similar conclusions have been drawn in the retailing sector. In an article by Sue Mitchell in The Age ${ }^{36}$, exposing a lack of retailer board knowledge of the retail sector, one commentator concluded that 'the role of the board is to OK the broad path they expect a company to follow; to be able to do that they must have a good understanding of the retail market and how it functions and what trends are important. ... If they are not alert to it, ... mistakes can be made.'

\footnotetext{
${ }^{35}$ European Commission, (2010). COMMISSION STAFF WORKING DOCUMENT Corporate Governance in Financial Institutions: Lessons to be drawn from the current financial crisis, best practices Accompanying document to the GREEN PAPER Corporate governance in financial institutions and remuneration policies. [online] Brussels: European Commission. Available at: http://tinyurl.com/awmq2xn

${ }^{36}$ Sue Mitchell, Retailer boards short of hands-on retail experience, The Age 30 May 2015 Available at: http://tinyurl.com/psn2gy2
} 


\subsubsection{Reasons cited in various research papers for using independent directors - do they} apply to superannuation funds?

\begin{tabular}{|c|c|c|}
\hline Reasons cited for independent directors & $\begin{array}{l}\text { Application to } \\
\text { Australian NFP* } \\
\text { superannuation } \\
\text { funds }\end{array}$ & $\begin{array}{l}\text { How NFP* superannuation funds } \\
\text { governance models exceed reasons } \\
\text { cited for independent directors }\end{array}$ \\
\hline $\begin{array}{l}\text { Helps manage the divergence between the } \\
\text { interests of shareholders and management }\end{array}$ & No & $\begin{array}{l}\text { SIS and Trust law require board to act } \\
\text { in members' best interest. } \\
\text { No shareholders and exist only to } \\
\text { benefit members. }\end{array}$ \\
\hline $\begin{array}{l}\text { Encourages active performance managing } \\
\text { of organisational performance particularly } \\
\text { in environments where there are executives } \\
\text { on the board }\end{array}$ & Yes & $\begin{array}{l}\text { APRA monitoring of performance, } \\
\text { regular reporting to APRA, } \\
\text { demonstration of scale and efficiency } \\
\text { as part of MySuper. }\end{array}$ \\
\hline $\begin{array}{l}\text { Role in take-over defences and acquisitions } \\
\text { as removed from management }\end{array}$ & No & $\begin{array}{l}\text { Best interests of all members. Due } \\
\text { diligence processes require board to } \\
\text { examine 'equivalency' of benefits. }\end{array}$ \\
\hline Good monitor of executive pay & Yes & $\begin{array}{l}\text { Remuneration committees and no } \\
\text { executives on boards }\end{array}$ \\
\hline $\begin{array}{l}\text { Helps access to international capital } \\
\text { markets }\end{array}$ & Yes & \\
\hline Some argue improves performance & $\mathrm{NFP}^{*}$ out-perform ${ }^{37}$ & \\
\hline
\end{tabular}

\section{Part Three - How Not for Profit Superannuation Fund Governance Meets ASX and Australian Bank/Insurance Standards}

As mentioned in the Overview within this paper, the Government has issued a Better Regulation and Governance, Enhanced Transparency and Improved Competition in Superannuation Discussion Paper. The Government's Discussion Paper states that it intends to align the governance structures in the superannuation system more closely with corporate governance principles and cites the ASX principles and the principles APRA applies to banking and insurance.

Accordingly, this section of the paper compares the corporate governance practices and requirements of ASX listed companies, banks and insurers with not-for-profit superannuation boards. The conclusion may be drawn that not-for-profit superannuation fund boards not only meet the vast majority of these requirements but - because of the overarching requirement that they must act in the best interests of members (based in trust law and legislation) - have higher corporate governance responsibilities.

\footnotetext{
${ }^{37}$ Industry Super Australia, (2015). Industry super fund outperformance reinforces undivided loyalty model | Industry Super Australia. [online] Available at http://tinyurl.com/jwcc3qe [Accessed 13 March 2015].
} 


\subsection{ASX Principles}

The table below compares APRA regulated super funds with the ASX

\begin{tabular}{|c|c|c|}
\hline ASX principle & Compliance & Representative model \\
\hline $\begin{array}{l}\text { Lay solid foundations for management and } \\
\text { oversight: } \\
\text { A listed entity should establish and disclose the } \\
\text { respective roles and responsibilities of its board and } \\
\text { management and how their performance is } \\
\text { measured and monitored. }\end{array}$ & $\sqrt{ }$ & $\begin{array}{l}\text { Governance Standard SPS } 510 \text { requires } \\
\text { that the board has a formal charter setting } \\
\text { out the roles and responsibilities, that any } \\
\text { delegation be clearly documented, and } \\
\text { that there be a process for performance } \\
\text { assessment. }\end{array}$ \\
\hline $\begin{array}{l}\text { Structure the board to add value: } \\
\text { A listed entity should have a board of appropriate } \\
\text { size, composition, skills and commitment to enable } \\
\text { it to discharge its duties effectively. }\end{array}$ & $\sqrt{ }$ & $\begin{array}{l}\text { Fit and Proper Standard SPS } 520 \\
\text { requires this. }\end{array}$ \\
\hline $\begin{array}{l}\text { Act ethically and responsibly: A listed entity should } \\
\text { act ethically and responsibly. }\end{array}$ & $\sqrt{ }$ & $\begin{array}{l}\text { SIS covenants sections } 52 \text { and } 52 \mathrm{~A} \text {. } \\
\text { AND additional common law trustee } \\
\text { duties }\end{array}$ \\
\hline $\begin{array}{l}\text { Safeguard integrity in corporate reporting: } \\
\text { A listed entity should have formal and rigorous } \\
\text { processes that independently verify and safeguard } \\
\text { the integrity of its corporate reporting. }\end{array}$ & $\sqrt{ }$ & $\begin{array}{l}\text { Funds are required to have internal } \\
\text { audit, external audit and in many } \\
\text { cases actuarial oversight with an audit } \\
\text { committee being required under SPS } \\
510\end{array}$ \\
\hline $\begin{array}{l}\text { Make timely and balanced disclosure: A listed } \\
\text { entity should make timely and balanced disclosure } \\
\text { of all matters concerning it that a reasonable person } \\
\text { would expect to have a material effect on the price } \\
\text { or value of its securities. }\end{array}$ & $\sqrt{ }$ & $\begin{array}{l}\text { SIS Act requires annual reports, } \\
\text { significant event notices, PDSs. Section } \\
29 \text { QB SIS Act requires additional } \\
\text { disclosures. }\end{array}$ \\
\hline $\begin{array}{l}\text { Respect the rights of security holders: A listed } \\
\text { entity should respect the rights of its security } \\
\text { holders by providing them with appropriate } \\
\text { information and facilities to allow them to exercise } \\
\text { those rights effectively. }\end{array}$ & N/a & $\begin{array}{l}\text { Arguably a higher test: SIS requires best } \\
\text { interest test for all members and } \\
\text { beneficiaries. Additional trustee common } \\
\text { law overlay. }\end{array}$ \\
\hline $\begin{array}{l}\text { Recognise and manage risk: } \\
\text { A listed entity should establish a sound risk } \\
\text { management framework and periodically review } \\
\text { the effectiveness of that framework. }\end{array}$ & $\sqrt{ }$ & $\begin{array}{l}\text { Risk Management Standard SPS } 220 \\
\text { requires this. }\end{array}$ \\
\hline $\begin{array}{l}\text { Remunerate fairly and responsibly: A listed entity } \\
\text { should pay director remuneration sufficient to } \\
\text { attract and retain high quality directors and design } \\
\text { its executive remuneration to attract, retain and } \\
\text { motivate high quality senior executives and to align } \\
\text { their interests with the creation of value for security } \\
\text { holders. }\end{array}$ & $\sqrt{ }$ & $\begin{array}{l}\text { SPS } 510 \text { requires super funds to have } \\
\text { remuneration policy and remuneration } \\
\text { committee. S29QB of SIS Act (via Regs) } \\
\text { requires extensive remuneration } \\
\text { disclosure. } \\
\text { Arguably a higher test of acting for } \\
\text { beneficiaries: SIS requires best interest } \\
\text { test for all members and beneficiaries. }\end{array}$ \\
\hline
\end{tabular}




\subsection{ASX listing rules}

The table below examines how APRA regulated superannuation funds compare with meeting the recommended ways for meeting the ASX principles as well as the 2013 recommendations.

Where not-for-profit superannuation boards would meet recommended methods

\begin{tabular}{|c|c|}
\hline ASX & Representative model \\
\hline $\begin{array}{l}\text { Charter setting out roles, responsibilities of board, } \\
\text { chair, senior management }\end{array}$ & SPS 510 \\
\hline Checks of candidates & SPS 520 \\
\hline $\begin{array}{l}\text { Board terms, written agreements with directors, } \\
\text { senior executives }\end{array}$ & SPS 510 board terms \\
\hline $\begin{array}{l}\text { Gender diversity policy and disclosure of meeting } \\
\text { targets }\end{array}$ & $\begin{array}{l}\text { AIST recommendation. WGEA applies where entity } \\
>100 \text { employees }\end{array}$ \\
\hline Board evaluation and disclosure & SPS 510 requires annual review \\
\hline Senior executive review & Occurs in practice \\
\hline $\begin{array}{l}\text { Disclose details of directors, interests, length of } \\
\text { service }\end{array}$ & New SIS regulations pursuant to s29QB SIS Act \\
\hline Chair and CEO not to be same person & Occurs in practice \\
\hline Entity should have statement of mix of skills & $\begin{array}{l}\text { S29QB SIS requires skills disclosure on web and mix } \\
\text { of skills required pursuant to SPS } 510 \text { and SPS } 520\end{array}$ \\
\hline Board should have audit committee & Requirement under SPS 510 \\
\hline $\begin{array}{l}\text { Board should receive statement from } \mathrm{CEO} \text { and } \mathrm{CFO} \\
\text { that accounts properly maintained }\end{array}$ & Occurs \\
\hline $\begin{array}{l}\text { Board to require management to design and report on } \\
\text { risk management and review at least annually and } \\
\text { major risks identified and reported }\end{array}$ & A requirement under SPS 220 \\
\hline $\begin{array}{l}\text { Board should establish remuneration committee with } \\
\text { majority of independents and claw back policy of } \\
\text { performance based remuneration and disclose this } \\
\text { policy as well as equity based remuneration schemes }\end{array}$ & $\begin{array}{l}\text { Remuneration committee required SPS } 510 \text { and claw } \\
\text { back policy of performance based remuneration and } \\
\text { disclose this policy and equity based schemes }\end{array}$ \\
\hline
\end{tabular}

\section{Grey area}

\begin{tabular}{ll} 
Majority to be independent directors. & AIST member fund trustees are non-executive and \\
ASX defines independent as "a non-executive & appointed by external entities. Additionally, SIS Act \\
director who is not a member of management and & and common law trustee duties of care impose best \\
who is free of any business or other relationship that & interests of member tests. Research demonstrates term \\
could materially interfere with or could reasonably & trustee imposes seriousness of role with fewer breaches \\
$\begin{array}{ll}\text { be perceived to materially interfere with the } & \text { than corporate directors (see 2006 PJC on Corporations } \\
\text { independent exercise of their judgment". } & \text { and Financial Services Inquiry into Structure and Op of } \\
& \text { Superannuation Industry). }\end{array}$ \\
\hline
\end{tabular}

\section{Where not-for-profit superannuation boards would not meet recommended method}

\begin{tabular}{ll}
\hline Chair to be independent & $\begin{array}{l}\text { Not required, though many have elected to appoint an } \\
\text { independent Chair }\end{array}$ \\
\hline Board should establish nomination committee & $\begin{array}{l}\text { Not required BUT super funds required to have board } \\
\text { renewal policy SPS 510 }\end{array}$ \\
$\begin{array}{l}\text { Code of conduct for board, senior executives and } \\
\text { employees }\end{array}$ & $\begin{array}{l}\text { Not a requirement, but AIST supports this and is } \\
\text { common practice. AIST introduced Code of Conduct } \\
\text { and Ethics for its members in 2014 }\end{array}$ \\
$\begin{array}{l}\text { Audit committee should include at least 3 non- } \\
\text { executive directors and majority are independent and } \\
\text { Chair is independent and not Chair of board }\end{array}$ & $\begin{array}{l}\text { At least 3 members, all non-executive. Chair of } \\
\text { committee not to be Chair of the Board - SPS 510. }\end{array}$ \\
$\begin{array}{l}\text { Communications policy for effective communication } \\
\text { with shareholders and participation at gen'l meetings }\end{array}$ & $\begin{array}{l}\text { Not a requirement but SIS Act covers major member } \\
\text { communications. }\end{array}$ \\
\hline
\end{tabular}




\subsection{Comparing Prudential Standards for banks and insurance with not-for- profit superannuation funds}

As previously noted, the Government's Discussion Paper states that it intends to align the governance structures in the superannuation system with the principles APRA applies to banking and insurance.

Prudential Standard CPS 510 Governance sets out minimum foundations for good governance of Approved Deposit-taking Institutions, general and life insurers:

- Competent (or similar) board which can make reasonable and impartial business judgments in the best interests of the institution and which duly considers the impact of its decisions on depositors or policy holders. The governance of these institutions builds on these foundations in risk that sponsoring organisations dictate ways that take account of the institutions size, complexity and risk profile.

- 'Independent director' is a non-executive director who is free from any business or other association - including those arising out of a substantial shareholding, involvement in past management or as a supplier, customer or adviser - that could materially interfere with the exercise of their independent judgment. The circumstances that will not meet this test of independence include, but are not limited to, those set out in Attachment A below:

(Attachment A) A director is not independent if the director:

1. is a substantial shareholder of the regulated institution or an officer of, or otherwise associated directly with, a substantial shareholder of the regulated institution;

2. is employed, or has previously been employed, in an executive capacity by the regulated institution or another group member, and there has not been a period of at least three years between ceasing such employment and serving on the Board;

3. has within the last three years been a principal of a material professional adviser or material consultant to the regulated institution or another group member, or an employee materially associated with the service provided;

4. is a material supplier or customer of the regulated institution or another group member, or an officer f or otherwise associated directly or indirectly with a material supplier or customer; or

5. has a material contractual relationship with the regulated institution or another group member other than as a director.

A non-executive director is interpreted as meaning reference to a director who is not a member of the regulated institution's management. Non-executive directors may include Board members, senior managers of parent company of locally incorporated regulated institution or of parent company's subsidiaries, but not executives of the regulated institution or its subsidiaries. 


\section{Comparing CPS 510 requirements with superannuation funds:}

\begin{tabular}{|c|c|}
\hline CPS 510 requirement & Superannuation fund requirements \\
\hline \multicolumn{2}{|l|}{ APRA key requirements: } \\
\hline $\begin{array}{l}\text { Specific requirements of board size and composition } \\
\text { which include: }\end{array}$ & $\begin{array}{l}\text { Requirements under APRA Prudential Standards } \\
\text { include: }\end{array}$ \\
\hline - full range of skills & - same requirement SPS 520 fit and proper \\
\hline - collective knowledge of directors & - same requirement SPS 520 fit and proper \\
\hline - minimum 5 directors & - not a requirement \\
\hline - majority of independent directors & - not a requirement but no executive directors \\
\hline - Chair must be independent & - not a requirement but no executive directors \\
\hline $\begin{array}{l}\text { - Majority of directors present and eligible to vote at } \\
\text { all board meetings must be non-executive directors }\end{array}$ & $\begin{array}{l}\text { - not a requirement but no executive directors on } \\
\text { trustee boards }\end{array}$ \\
\hline $\begin{array}{l}\text { Board representation must be consistent with locally } \\
\text { incorporated regulated institutions shareholding. CPS } \\
\text { gives examples eg. if shareholding is no more than } \\
15 \% \text { of voting shares, not be more than } 1 \text { board } \\
\text { member who is an associate of shareholder. }\end{array}$ & $\begin{array}{l}\text { Board represents best interests of all members so not a } \\
\text { requirement. }\end{array}$ \\
\hline Chair must be independent director & $\begin{array}{l}\text { Not a requirement although some of AIST member } \\
\text { funds have independent directors as chairs }\end{array}$ \\
\hline Board Audit Committee must be established & Same requirement as SPS 510 Governance \\
\hline $\begin{array}{l}\text { Board must have policy on Board renewal and } \\
\text { procedures for assessing Board performance }\end{array}$ & Same requirement as SPS 510 Governance \\
\hline Board Remuneration Committee must be established & Same requirement as SPS 510 Governance \\
\hline \multicolumn{2}{|l|}{ Other APRA requirements } \\
\hline $\begin{array}{l}\text { Institution must have a Remuneration Policy aligning } \\
\text { remuneration and risk management }\end{array}$ & Same requirement as SPS 510 Governance \\
\hline $\begin{array}{l}\text { Institution must have dedicated internal audit } \\
\text { function }\end{array}$ & Same requirement as SPS 510 Governance \\
\hline
\end{tabular}

\section{International reflections on the value of the trust structure}

In its Interim Report, the Financial System Inquiry sought views on the appropriateness and cost efficiency of the trust structure for the superannuation industry. The Inquiry has generally expressed interest in seeking comments on international comparisons with the Australian financial system. This section therefore examines - and confirms - the international view that trust structures best protect members and their beneficiaries.

The legal framework that trustee directors operate in is based on trust law. This sets the limits of a trustee's discretionary powers and assigns duties and obligations to protect the interests of beneficiaries. Many commentators believe the trust structure is fundamental to a retirement savings system that ensures the highest standards of governance. A recent report by the Law Commission ${ }^{38}$ in the UK examined the nature of trust law around fiduciary duties. The report considered these duties in the context of the UK pension fund system, and the difference in duties of fiduciaries, and the protection of beneficiaries, across pension funds based in trust law, and those created in a contractual relationship. The report quotes Lord Justice Millett's summary of a fiduciary relationship in Bristol and West Building Society v Mothew: "The principal is entitled to the single-minded loyalty of his fiduciary. This core liability has several facets. A fiduciary must act in good faith; he must not make a profit out of his trust; he must not place himself in a position where his duty and his interest may conflict; he may not act for his own benefit or the benefit of a third person without the informed consent of his principal. This is not intended to be an exhaustive list, but it is sufficient to indicate the nature of fiduciary obligations. They are the defining characteristics of the fiduciary." "The distinguishing duty of a fiduciary is "the duty to loyalty". However this duty of loyalty sits alongside the other statutory, equitable and common law duties which a fiduciary might owe."

\footnotetext{
${ }^{38}$ Law Commission UK (July 2014) Fiduciary Duties of Investment Intermediaries available at: http://tinyurl.com/kaeor5a
} 
In the UK there are two separate and very different legal foundations underpinning pension funds those based in trust law and those based in contract. An individual can purchase a pension product from an insurer in the UK, and that is a product based in contract law. Reviewing the two systems, however, the Law Commission report noted: "There are serious problems with the law relating to contract-based pensions. The contract model assumes that savers are fully informed autonomous parties, able to make good judgements in the market place. Yet the evidence is that savers fail to engage with pensions. This has now become institutionalised by auto-enrolment, where people are placed in pension schemes by default, without any conscious agreement to the charges or contract terms." The report states that a distinguishing duty of fiduciary is their duty to loyalty to the beneficiaries of the trust. That duty of loyalty however sits alongside the other statutory, equitable and common law duties which a fiduciary might owe. In contract, the duty of loyalty, and the obligation to protect the best interests of the pension fund member are absent. In a pension scheme context trustees are asked to "make the decisions that members would have made for themselves, if they had the time, expertise and motivation to do so." The protection that trust law offers to the beneficiaries as vulnerable and disengaged members of pensions schemes is far higher and more appropriate in the circumstances than a relationship based in contract law

\section{Conclusion}

The Australian superannuation system is envied internationally. Australia's superannuation system now covers over $94 \%$ of the Australian workforce, ${ }^{39}$ has over $\$ 1.75$ trillion under management, and is equal to Australia's GDP. ${ }^{40}$ The majority of Australians rely on trustees to prudently manage their retirement savings. Australia's superannuation industry comprises several types of superannuation models, each with different governance and ownership structures. Some superannuation funds are owned by banks, some are owned by individuals (Self Managed Superannuation Funds), while the not-for-profit superannuation funds exist purely to manage money for the members and other beneficiaries.

While there are these different models, pooled superannuation funds (those funds not operated by individuals for their own retirement) have stringent governance requirements, via a combination of Commonwealth legislation and trust law. The application of trust law to Australian superannuation funds replicates other Anglo-Saxon jurisdictions. As Keith L Johnson and Frank Jan de Graaf note in an OECD paper $^{41}$, "trustees have generally been held to a higher standard of conduct than is required of corporate directors or parties to a contract."

The research of international corporate governance trends featured in this paper was undertaken as input to AIST's response to the Government's Discussion Paper. A review of papers from the OECD, the EU Commission, and various academic papers was undertaken and there was a very clear focus on corporate governance issues following the GFC. The findings are clear:

- Members of superannuation funds need representation on boards so that their interests are aligned.

- No case for having prescriptive requirements for independent directors has been made.

- The focus should be on outcomes.

- It is important that board members be suitably qualified and experienced (the APRA Prudential Standards in Australia cover this issue).

\footnotetext{
${ }^{39}$ Australian Bureau of Statistics, (2009). Trends in Superannuation Coverage. Available at: http://www.abs.gov.au/AUSSTATS/abs@nsf/Lookup/4102.0Main+Features70March\%202009

40 The Hon B Shorten (2013). Address at the Conference of Major Superannuation Funds. Brisbane. Available at: http://ministers.treasury.gov.au/DisplayDocs.aspx?doc=speeches/2013/002 htm\&pageID=005\&min= brs \&Year $=\&$ DocType $=$

${ }^{41}$ Johnson, K. and de Graaf, F. (2009). Modernising Pension Fund Legal Standards for the $21^{\text {st }}$ Century, Organisation for Economic Co-operation and Development. Available at:

http://www.oecd.org/corporate/ca/corporategovernanceprinciples/42670725.pdf Feb 2009
} 
The overriding requirement is that the board of trustees of superannuation funds must act in the best interests of members (and the beneficiaries of members). These stringent requirements have resulted in the Australian superannuation system receiving the second highest score out of 25 countries in the Mercer Global Pension Index. Within this environment, Australia's not-for-profit superannuation funds have outperformed ${ }^{42}$.

${ }^{42}$ Industry Super Australia, (2015). Industry super fund outperformance reinforces undivided loyalty model | Industry Super Australia. [online] Available at http://tinyurl.com/jwcc3qe [Accessed 13 March 2015]. 